\title{
Corrosion of Basic Refractories in Contact with Cement Clinker and Kiln Hot Meal
}

\author{
Jacek Szczerba, Ilona Jastrzębska, Zbigniew Pędzich, Mirosław M. Bućko \\ Department of Materials Science and Ceramics, AGH University of Science and Technology, Kraków, Poland \\ Email: jszczerb@agh.edu.pl
}

Received July 2014

\begin{abstract}
This paper investigates the new phases formation in the magnesia-spinel, magnesia-zirconia-calcia and magnesia-hercynite refractory products as a result of their reaction with kiln hot meal and cement clinker (both rich in $\mathrm{SO}_{3}$ and $\mathrm{Cl}$ ions) at the temperature range $1200^{\circ} \mathrm{C}-1450^{\circ} \mathrm{C}$. The laboratory corrosion tests were conducted by means of pulverous method and by special coating test. The phase identity of the products as well as the mixes after corrosion tests was established by powder X-ray diffraction method. The microstructure development of the contact zones between coating and the products were studied using scanning electron microscopy SEM with EDS spectroscopy. The differences in the reactions proceeding between the phases of the test bricks and the phases of kiln hot meal and cement clinker in dependence on the temperatures have been discussed.
\end{abstract}

\section{Keywords}

Corrosion, Refractories, Clinker, $\mathrm{CaZrO}_{3}, \mathrm{MgO} \mathrm{FeAl}_{2} \mathrm{O}_{4}$

\section{Introduction}

During work of basic refractory lining in the sintering zone of rotary kiln devoted for sintering of Portland clinker, the components of the products undergo an intensive interaction in the first place. This is associated with the influence of the highest temperatures in the sintering zone of the kiln. The length of it is usually identified with the range of temperatures of the shifting furnace charge, where chemical processes of phase composition formation of Portland clinker occur in the presence of a liquid phase [1] [2]. The liquid phase in the system of basic oxide components $\mathrm{CaO}-\mathrm{SiO}_{2}-\mathrm{Al}_{2} \mathrm{O}_{3}-\mathrm{Fe}_{2} \mathrm{O}_{3}$ of cement clinker occurs in zero-point of $\mathrm{C}_{3} \mathrm{~S}-\mathrm{C}_{2} \mathrm{~S}-\mathrm{C}_{3} \mathrm{~A}-$ $\mathrm{C}_{4} \mathrm{AF}$ subsystem at the temperature of $1338^{\circ} \mathrm{C}$ [3]. The liquid phase may occur earlier at the temperature about $1280^{\circ} \mathrm{C}$, what is related with eutectic in the system $\mathrm{C}_{2} \mathrm{~S}-\mathrm{C}_{12} \mathrm{~A}_{7}-\mathrm{C}_{2}(\mathrm{~A}, \mathrm{~F})$. Moreover, presence of $\mathrm{MgO}$ and $\mathrm{R}_{2} \mathrm{O}$ oxides $\left(\mathrm{R}=\mathrm{K}, \mathrm{Na}\right.$ ) lowers the temperature of liquid phase occurrence to about $1260^{\circ} \mathrm{C}$ [4]. The earlier appearance of the liquid phase is associated with eutectic in $\mathrm{CF}_{-} \mathrm{CF}_{2}$ system occurring at approximately $1200^{\circ} \mathrm{C}$.

Nowadays, the magnesia-spinel products have the biggest share among many types of the basic products that are devoted for the application as linings in the sintering zone of cement kilns [5]-[7]. The corrosion process, besides wear by erosion and abrasion, is one of the crucial importances limiting the lifetime of the refractory lining. Therefore, this work aims to investigate the high temperature behaviour (from $1200^{\circ} \mathrm{C}$ to $1450^{\circ} \mathrm{C}$ ) of a 
few important, in the cement industry, basic refractories—magnesia-spinel MSp, magnesia-zirconia-calcia MCZ and magnesia-hercynite MH products. The present work was undertaken in order to get a better recognize and understanding of reactions between the components of the bricks and the furnace charge, leading to formation of the new phases.

\section{Experimental Methods}

The materials taken to investigation were industrial magnesia-spinel (MSp), magnesia-zirconia-calcia (MCZ) and magnesia-hercynite (MH) products (Table 1). Hot kiln meal enriched with alkali oxides, $\mathrm{SO}_{3}$ and chlorine and Portland clinker produced out of it (Table 1) were applied as the corrosive media in the present study. The meal and clinker came from the cement rotary kiln working with precalciner system and using alternative fuels. The corrosion test was carried out in the temperature range from $1200^{\circ} \mathrm{C}$ to $1450^{\circ} \mathrm{C}$, corresponding to the temperatures of the shifting furnace charge in the segment of the sintering zone of cement rotary kiln, considering the changes in its phase composition during the sintering process [1] [2].

The examined materials from cement kiln came from often encountered system with an excess of $\mathrm{SO}_{\mathrm{x}}$ and with the high amount of $\mathrm{Cl}^{-}$ions, over alkali oxides level occurring in the kiln atmosphere. That is the reason for the low molar alkali sulphate module, designated as ASR (Table 1). Both for kiln hot meal and Portland clinker the ASR module took a value below 1 [2].

Table 1. The chemical and phase composition of the materials taken to examination.

\begin{tabular}{|c|c|c|c|c|c|}
\hline \multirow{3}{*}{ Specification } & \multicolumn{5}{|c|}{ Chemical composition, wt.\% } \\
\hline & \multicolumn{3}{|c|}{ Product ${ }^{1)}$} & \multicolumn{2}{|c|}{ Corrosive media } \\
\hline & MSp & $\mathrm{MCZ}$ & $\mathrm{MH}$ & $\begin{array}{c}\text { Kiln hot meal } \\
\text { (without loss of ignition) }\end{array}$ & $\begin{array}{c}\text { Portland clinker } \\
\text { (without loss of ignition) }\end{array}$ \\
\hline $\mathrm{SiO}_{2}$ & 0.3 & 0.30 & 1.0 & 19.78 & 20.67 \\
\hline $\mathrm{CaO}$ & 0.9 & 5.59 & 2.0 & 63.14 & 64.32 \\
\hline $\mathrm{Al}_{2} \mathrm{O}_{3}$ & 5.6 & 0.15 & 2.9 & 6.11 & 6.22 \\
\hline $\mathrm{Fe}_{2} \mathrm{O}_{3}$ & 0.4 & 0.42 & 8.1 & 2.46 & 3.07 \\
\hline $\mathrm{MgO}$ & 92.8 & 82.74 & 85.3 & 1.75 & 2.03 \\
\hline $\mathrm{ZrO}_{2}$ & - & 10.63 & - & - & - \\
\hline $\mathrm{C} / \mathrm{S}_{\mathrm{wt}}$ & 3.0 & 18.6 & 2.0 & - & - \\
\hline $\mathrm{K}_{2} \mathrm{O}$ & - & - & - & 1.73 & 1.44 \\
\hline $\mathrm{Na}_{2} \mathrm{O}$ & - & - & - & 0.12 & 0.13 \\
\hline $\mathrm{SO}_{3}$ & - & - & - & 4.92 & 2.46 \\
\hline $\mathrm{Cl}-$ & - & - & - & 3.54 & 0.00 \\
\hline
\end{tabular}

Modules (refer to corrosive media only)/dimensionless unit

\begin{tabular}{|c|c|c|c|c|c|}
\hline Lime saturation factor, LSF ${ }^{2)}$ & - & - & - & 95.2 & 92.9 \\
\hline Silica ratio, $\mathrm{SR}^{3)}$ & - & - & - & 2.3 & 2.2 \\
\hline Alumina ratio, $\mathrm{AR}^{4)}$ & - & - & - & 2.5 & 2.0 \\
\hline Liquid phase, $\mathrm{LP}_{1450}^{5)}$ & - & - & $\cdot$ & 27.5 & 28.8 \\
\hline Alkali sulphate module, ASR $^{6)}$ & - & - & - & -0.48 & 0.45 \\
\hline
\end{tabular}

Theoretical phase composition ${ }^{7)}$ of MSp.:M, MA, $\mathrm{C}_{2} \mathrm{~S}, \mathrm{C}_{3} \mathrm{~A}$; MCZ: M, CZ; MH:M, F ${ }^{2+} \mathrm{A}, \mathrm{M}(\mathrm{A}, \mathrm{F}), \mathrm{C}_{2} \mathrm{~S}$, Portland clinker according to Bogue [8],wt. \% ${ }^{7}$ : $\mathrm{C}_{3} \mathrm{~S}-58,6 ; \mathrm{C}_{2} \mathrm{~S}-15,1 ; \mathrm{C}_{3} \mathrm{~A}-11,3 ; \mathrm{C}_{4} \mathrm{AF}-9,4 ; \mathrm{CaSO}_{4}-4,2$.

${ }^{1)}$ Symbols according to the standard PN-EN [9]; ${ }^{2)} \mathrm{LSF}_{\mathrm{A} / \mathrm{R}>0.638}=100 \cdot \mathrm{CaO} /\left(2,8 \cdot \mathrm{SiO}_{2}+1.65 \cdot \mathrm{Al}_{2} \mathrm{O}_{3}+0.35 \cdot \mathrm{Fe}_{2} \mathrm{O}_{3}\right) ;{ }^{3)} \mathrm{SR}=\mathrm{SiO}_{2} /\left(\mathrm{Al}_{2} \mathrm{O}_{3}+\mathrm{Fe}_{2} \mathrm{O}_{3}\right) ;{ }^{4} \mathrm{AR}$ $=\mathrm{Al}_{2} \mathrm{O}_{3} / \mathrm{Fe}_{2} \mathrm{O}_{3} ;{ }^{5} \mathrm{LP}_{1450}=3.0 \cdot \mathrm{Al}_{2} \mathrm{O}_{3}+2.25 \cdot \mathrm{Fe}_{2} \mathrm{O}_{3}+\mathrm{MgO}+\mathrm{Na}_{2} \mathrm{O}+\mathrm{K}_{2} \mathrm{O} ;{ }^{6} \mathrm{ASR}=\left(\mathrm{K}_{2} \mathrm{O} / 94+\mathrm{Na}_{2} \mathrm{O} / 62-\mathrm{Cl}_{2} / 71\right) /\left(\mathrm{SO}_{3} / 80\right) ;{ }^{7} \mathrm{M}-\mathrm{MgO} ; \mathrm{A}-\mathrm{Al}_{2} \mathrm{O}_{3} ;$ $\mathrm{C}-\mathrm{CaO} ; \mathrm{S}-\mathrm{SiO}_{2} ; \mathrm{F}_{-}-\mathrm{Fe}_{2} \mathrm{O}_{3} ; \mathrm{f} / \mathrm{F}^{2+}-\mathrm{FeO} ; \mathrm{Z}-\mathrm{ZrO}_{2}$ 
The X-ray powder analysis of Portland clinker showed, besides the main phase of alite $\mathrm{C}_{3} \mathrm{~S}$, presence of the phases such as: belite $\beta-\mathrm{C}_{2} \mathrm{~S}$, tri-calcium aluminate $\mathrm{C}_{3} \mathrm{~A}$ and calcium aluminoferrite phase corresponding to the structure of $\mathrm{C}_{4} \mathrm{AF}$ type. The determined phase composition of Portland clinker by XRD is agreeable with the theoretical one calculated according to Bogue [8] (Table 1).

The XRD analysis of the kiln hot meal sample showed the presence of belite $\beta-C_{2} S$, mayenite $C_{12} A_{7}$, anhydrite $\mathrm{CaSO}_{4}$, sylvine $\mathrm{KCl}$, quartz $\mathrm{SiO}_{2}$ and remains of calcium carbonate $\mathrm{CaCO}_{3}$. On the other hand, after calcining of kiln hot meal at $1200^{\circ} \mathrm{C} / 2 \mathrm{~h}$, it exhibited the presence of belite $\beta-\mathrm{C}_{2} \mathrm{~S}$, calcium sulphate aluminate-yeelimite $\mathrm{C}_{3} \mathrm{~A}_{3} \cdot \mathrm{CaSO}_{4}$, aluminoferrite phase corresponding to structure $\mathrm{C}_{4} \mathrm{AF}$, mayenite $\mathrm{C}_{12} \mathrm{~A}_{7}$ and traces of potassium chloride $\mathrm{KCl}$. These are the typical intermediate phases appearing at this stage of sintering of Portland clinker.

The corrosion test of the products was carried out by means of the pulverous and special coating method [10]. The mixtures for the corrosion test by pulverous method consisted of the product/kiln hot meal or Portland clinker in mass ratio (3:1).

Before the materials to be examined were prepared, the subsequently, the mixtures were moulded into pellets of mixtures were milled to obtain granulation $<0.063 \mathrm{~mm}$. Subsequently, the mixtures were moulded into pellets of $20 \mathrm{~mm}$ in diameter and $10 \mathrm{~mm}$ in thickness under the pressure of $100 \mathrm{MPa}$. Then, the pellets were heated up to $1200^{\circ} \mathrm{C}$ (with kiln hot meal), $1300^{\circ} \mathrm{C}$ and $1400^{\circ} \mathrm{C}$ (with Portland clinker) with 2 hours soaking time at each temperature and then cooled down together with the laboratory electric furnace. Such samples were then milled to granulation $<0.063 \mathrm{~mm}$ and their phase composition was determined by XRD.

For the corrosion test by coating method the disks of $30 \mathrm{~mm}$ in diameter and $20 \mathrm{~mm}$ in height were bored from the products. The surface of the discs was ground and then they were pressed with kiln hot meal or Portland clinker, of granulation $<0.063 \mathrm{~mm}$, in a mould of $50 \mathrm{~mm}$ in diameter, under the pressure of $50 \mathrm{MPa}$. Thus, the disks were covered both on the side rim as well as the upper surface with the layer of kiln hot meal and cement clinker.

The samples with Portland clinker for the coating corrosion test were heated up to $1450^{\circ} \mathrm{C}$ with 5 hours soaking time at each temperature and cooled down together with the laboratory electric furnace. The metallographic specimens were prepared from the after-coating corrosion samples for the microstructure observations under Scanning Electron Microscope (SEM) equipped with EDS detector for chemical analysis in microareas. The starting products were also subjected to SEM/EDS analysis.

\section{Results and Discussion}

\subsection{Products of the Reactions in the Powder Mixtures Examined by Pulverous Corrosion Method}

Table 2 and Table 3 contains results of the phase composition analysis of the mixtures product/kiln hot meal or Portland clinker after heating up to $1200^{\circ} \mathrm{C}$ (kiln hot meal), and $1300^{\circ} \mathrm{C}, 1400^{\circ} \mathrm{C}$ (Portland clinker). As it can be observed from Table 2, in reaction of the mixture of MSp product with kiln hot meal at the temperature of $1200^{\circ} \mathrm{C}$, spinel MA almost totally disappeared from the product and calcium aluminate $\mathrm{C}_{12} \mathrm{~A}_{7}$ was produced. Moreover, the presence of $\mathrm{C}_{3} \mathrm{~A}_{3} \cdot \mathrm{CaSO}_{4}$ phase as well as merwinite and brownmillerite was detected in the material.

In the case of $\mathrm{MCZ}$ product $\mathrm{MgO}, \mathrm{CaZrO}_{3}$ and $\beta-\mathrm{Ca}_{2} \mathrm{SiO}_{4}$ were identified as the major phases, while $\mathrm{C}_{3} \mathrm{~A}_{3} \cdot \mathrm{CaSO}_{4}, \mathrm{C}_{4} \mathrm{AF}, \mathrm{C}_{3} \mathrm{~A}$ were present in the minor amounts. This shows that the main constituents of the MCZ

Table 2. Phase composition of the mixtures (3:1) (product/kiln hot meal) after heating up to $1200^{\circ} \mathrm{C}$.

\begin{tabular}{|c|c|}
\hline Sample & Phases identified in the test material by XRD (in order of lower intensity) \\
\hline Kiln hot meal & $\beta-\mathrm{Ca}_{2} \mathrm{SiO}_{4}, \mathrm{C}_{12} \mathrm{~A}_{7}, \mathrm{CaSO}_{4}, \mathrm{KCl}, \mathrm{SiO}_{2}$, remains of $\mathrm{CaCO}_{3}$ \\
\hline $\mathrm{MSp} / \mathrm{khm}^{\mathrm{a}}$ & $\mathrm{MgO}, \beta-\mathrm{Ca}_{2} \mathrm{SiO}_{4}, \mathrm{MgAl}_{2} \mathrm{O}_{4} \downarrow, \mathrm{C}_{12} \mathrm{~A}_{7}, \mathrm{C}_{3} \mathrm{~A}_{3} \cdot \mathrm{CaSO}_{4}, \mathrm{C}_{3} \mathrm{MS}_{2}, \mathrm{C}_{4} \mathrm{AF}$ \\
\hline $\mathrm{MCZ} / \mathrm{khm}^{\mathrm{a}}$ & $\mathrm{MgO}, \mathrm{CaZrO}_{3}, \beta-\mathrm{Ca}_{2} \mathrm{SiO}_{4}, \mathrm{C}_{3} \mathrm{~A}_{3} \cdot \mathrm{CaSO}_{4}, \mathrm{C}_{4} \mathrm{AF}, \mathrm{C}_{3} \mathrm{~A}$ \\
\hline $\mathrm{MH} / \mathrm{khm}^{\mathrm{a}}$ & $\mathrm{MgO}, \beta-\mathrm{Ca}_{2} \mathrm{SiO}_{4}, \mathrm{C}_{4} \mathrm{AF}, \mathrm{Fe}_{3} \mathrm{O}_{4}$ \\
\hline
\end{tabular}

\footnotetext{
${ }^{\mathrm{a}}$ kiln hot meal.
} 
Table 3. Phase composition of the mixtures with (3:1) ratio (product/Portland clinker) after heating up to $1300^{\circ} \mathrm{C}$ and $1400^{\circ} \mathrm{C}$.

\begin{tabular}{|c|c|}
\hline Sample & Phases identified in the test material by XRD (in order of lower intensity) \\
\hline \multirow[t]{2}{*}{ Portland clinker } & $\mathrm{C}_{3} \mathrm{~S}, \beta-\mathrm{Ca}_{2} \mathrm{SiO}_{4}, \mathrm{C}_{3} \mathrm{~A}, \mathrm{C}_{4} \mathrm{AF}, \mathrm{CaSO}_{4}$ \\
\hline & Corrosion test at $1300^{\circ} \mathrm{C}$ \\
\hline $\mathrm{MSp} / \mathrm{Pc}^{\mathrm{b}}$ & $\mathrm{MgO}, \beta-\mathrm{Ca}_{2} \mathrm{SiO}_{4}, \mathrm{Q}-\mathrm{C}_{20} \mathrm{~A}_{13} \mathrm{M}_{3} \mathrm{~S}_{3}, \mathrm{C}_{3} \mathrm{~A}_{3} \cdot \mathrm{CaSO}_{4}, \mathrm{MgAl}_{2} \mathrm{O}_{4} \downarrow$ \\
\hline $\mathrm{MCZ} / \mathrm{Pc}^{\mathrm{b}}$ & $\mathrm{MgO}, \mathrm{CaZrO}_{3}, \mathrm{Ca}_{3} \mathrm{SiO}_{5}, \mathrm{C}_{4} \mathrm{AF}, \mathrm{C}_{3} \mathrm{~A}$ \\
\hline \multirow[t]{2}{*}{$\mathrm{MH} / \mathrm{Pc}^{\mathrm{b}}$} & $\mathrm{MgO}, \mathrm{C}_{4} \mathrm{AF}, \beta-\mathrm{Ca}_{2} \mathrm{SiO}_{4}$ \\
\hline & Corrosion test at $1400^{\circ} \mathrm{C}$ \\
\hline $\mathrm{MSp} / \mathrm{Pc}^{\mathrm{b}}$ & $\mathrm{MgO}, \beta-\mathrm{Ca}_{2} \mathrm{SiO}_{4}, \mathrm{C}_{2} \mathrm{AS}, \mathrm{Q}-\mathrm{C}_{20} \mathrm{~A}_{13} \mathrm{M}_{3} \mathrm{~S}_{3}$ \\
\hline $\mathrm{MCZ} / \mathrm{Pc}^{\mathrm{b}}$ & $\mathrm{MgO}, \mathrm{CaZrO}_{3}, \mathrm{Ca}_{3} \mathrm{SiO}_{5}, \mathrm{C}_{4} \mathrm{AF}, \mathrm{C}_{3} \mathrm{~A}$ \\
\hline $\mathrm{MH} / \mathrm{Pc}^{\mathrm{b}}$ & $\mathrm{MgO}, \mathrm{C}_{4} \mathrm{AF}, \beta-\mathrm{Ca}_{2} \mathrm{SiO}_{4}$ \\
\hline
\end{tabular}

${ }^{\mathrm{b}}$ Portland clinker.

product did not react during the corrosion test. The new phases, formed after the test, were a consequence of the reactions only between the components of hot kiln meal, and they constituted typical transitional phases appearing at $1200^{\circ} \mathrm{C}$ during sintering of cement clinker. Regarding magnesia-hercynite sample (MH), presence of periclase, alite and brownmillerite was detected after the corrosion test. Furthermore, a small amount of magnetite $\mathrm{Fe}_{3} \mathrm{O}_{4}$ was found in the discussed sample, probably as a consequence of hercynite decomposition and subsequent partial oxidation of $\mathrm{FeO}[11]$.

Table 3 shows phase composition of the mixtures in the mass ratio (3:1) (product/Portland clinker) after heating up to $1300^{\circ} \mathrm{C}$ and $1400^{\circ} \mathrm{C}$. The mixture of MSp product with Portland clinker, heated up to $1300^{\circ} \mathrm{C}$, exhibited almost total disappearance of spinel MA from the product, decomposition of silicate $\mathrm{C}_{3} \mathrm{~S}$ and aluminate phases, and calcium sulphate from Portland clinker (Table 1 and Table 3). As a result of the reaction new phases were formed, coexisting with $\mathrm{MgO}$ and $\mathrm{C}_{2} \mathrm{~S}$. They involve quaternary aluminate, so-called $\mathrm{Q}$ phase, which can be expressed by the formula $\mathrm{C}_{20} \mathrm{~A}_{13} \mathrm{M}_{3} \mathrm{~S}_{3}$ [12] and calcium sulphate aluminate $\mathrm{C}_{3} \mathrm{~A}_{3} \cdot \mathrm{CaSO}_{4}$, stable to $1350{ }^{\circ} \mathrm{C}$ [13]. However, in the mixture of MSp product with Portland clinker, heated up to $1400^{\circ} \mathrm{C}$, apart from $\mathrm{MgO}$ and $\mathrm{C}_{2} \mathrm{~S}$, new phases were found, which coexisted with them in sub-solidus. These were gehlenite $\mathrm{C}_{2} \mathrm{AS}$ and $\mathrm{Q}$ phase [12]. Since in the mixtures with MSp the $\mathrm{C}_{4} \mathrm{AF}$ phase disappeared, it may be expected that iron came within a solid solution (henceforth designated as “ss.”) with Q phase. Therefore the formula for this phase, earlier suggested by Parker as $\mathrm{C}_{6} \mathrm{~A}_{4} \mathrm{MS}$ (with incongruent melting point at $1380^{\circ} \mathrm{C}$ ), can not be excluded here - in this case with obvious substitutions of magnesium ions by ions of bivalent iron [8] [14].

The mixtures of MCZ product with Portland clinker, heated up to $1300^{\circ} \mathrm{C}$ and $1400^{\circ} \mathrm{C}$, exhibit the same phases occurrence at both temperatures of the test. In these mixtures XRD analysis enabled to identify the main components of the products- $\mathrm{CaZrO}_{3}$ and $\mathrm{MgO}$ as well as the main constituents of cement clinker- $\mathrm{C}_{3} \mathrm{~S}, \mathrm{C}_{3} \mathrm{~A}$ and $\mathrm{C}_{4} \mathrm{AF}$. The attained results imply that no reaction underwent between components of the MCZ product and the corrosive media.

As it comes to the $\mathrm{MH}$ product mixed with the cement clinker and subsequently sintered, at both $1300^{\circ} \mathrm{C}$ and $1400^{\circ} \mathrm{C}$ the same phases were identified. These were $\mathrm{MgO}, \mathrm{C}_{4} \mathrm{AF}$ and $\beta-\mathrm{Ca}_{2} \mathrm{SiO}_{4}$, where brownmillerite comprised the product of the reaction between hercynite decomposition products and $\mathrm{CaO}$. The lime was provided from the $\mathrm{C}_{3} \mathrm{~S}$ and $\mathrm{C}_{3} \mathrm{~A}$ decomposition, present in the Portland clinker. It is also proved by the disappearance of these phases in the after-corrosion sample.

\subsection{Phase Evolution and Microstructure Development of the Products after Coating Corrosion with Portland Clinker}

\subsubsection{Magnesia-Spinel Product (MSp)}

Base components of MSp product are periclase and spinel MA. This product consists of coarse-grained fraction of magnesia clinker, with low content of $\mathrm{Fe}_{2} \mathrm{O}_{3}$ oxide (Table 1) and fused spinel MA, surrounded by magnesia 
matrix (Figure 1). The additive phases of coarser grains of magnesia clinker are calcium silicate $\mathrm{C}_{2} \mathrm{~S}$ and tricalcium aluminate $\mathrm{C}_{3} \mathrm{~A}$, or rather their solid solutions. Those phases are dispersed among spinel and periclase grains. In the grains of fused spinel MA and in the magnesia matrix, the aluminate phases exist in the proximity of the latter as a solid solution $\mathrm{CA}-\mathrm{C}_{6} \mathrm{~A}_{4} \mathrm{MS}$.

In SEM image of the MSp product, after the reaction with the components of Portland clinker at $1450^{\circ} \mathrm{C}$ (Figure 2), changes were observed both in the range of matrix as well as in the area of bigger grains of magnesia clinker and fused spinel MA. In the product MSp, between the periclase crystals, prismatic crystals of Parker's phase of $\mathrm{C}_{6} \mathrm{~A}_{4}(\mathrm{M}, \mathrm{f}) \mathrm{S}$ type, crystallized out of liquid phase, which "moistened" them well. The elongated crystals of the $\mathrm{C}_{6} \mathrm{~A}_{4}(\mathrm{M}, \mathrm{f}) \mathrm{S}$ phase were integrated with periclase crystals and spinel MA, creating constant envelopes also around them. The determined chemical composition of the Parker's phase [8], carried out by method of chemical analysis in microarea (EDS), corresponds to the solid solution of the $\mathrm{C}_{6} \mathrm{~A}_{4} \mathrm{MS}-\mathrm{C}_{6} \mathrm{~A}_{4} \mathrm{fS}$ series. In this phase, oxides of $\mathrm{TiO}_{2}, \mathrm{~K}_{2} \mathrm{O}$ and $\mathrm{Na}_{2} \mathrm{O}$ were also dissolved in small amounts. Between crystals of $\mathrm{C}_{6} \mathrm{~A}_{4}(\mathrm{M}, \mathrm{f}) \mathrm{S}$, an aluminate-ferrite phase appeared, as a solid solution $\mathrm{C}_{2}(\mathrm{~A}, \mathrm{~F})$, enriched with $\mathrm{SiO}_{2}$. In the chemical composition of this phase, oxides of $\mathrm{MgO}$ and $\mathrm{TiO}_{2}$ were also detected. This oxides may, together with oxide $\mathrm{SiO}_{2}$ and phase $\mathrm{C}_{2}(\mathrm{~A}, \mathrm{~F})$, form the solid solutions [15] [16].

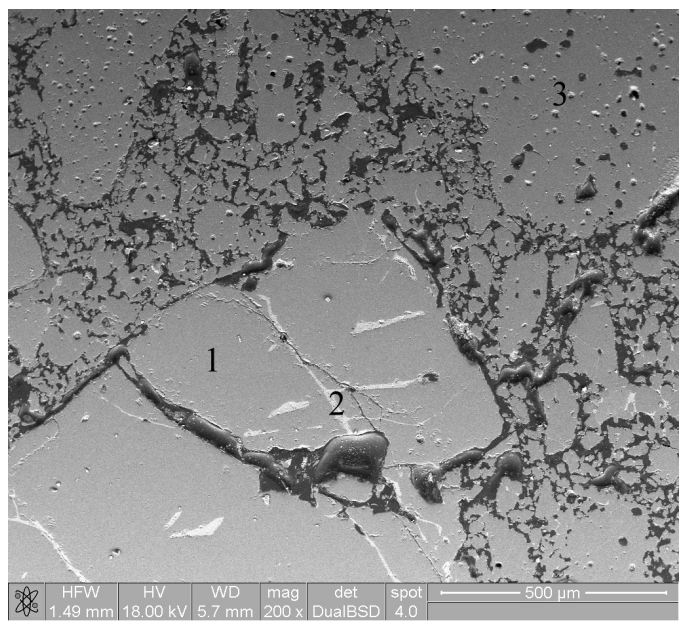

Figure 1. SEM image of the MSp product: spinel MA (1); aluminate phase ss. CA- $\mathrm{C}_{6} \mathrm{~A}_{4} \mathrm{MS}$ (2); grain of magnesia clinker (3); black areas are pores.

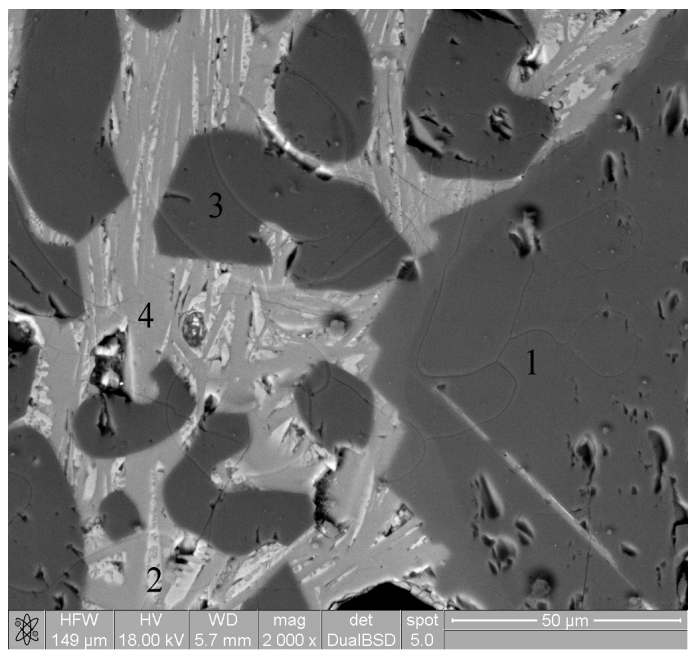

Figure 2. SEM image of the MSp product after corrosion by Portland clinker. Elongated crystals of Parker's phase $\mathrm{C}_{6} \mathrm{~A}_{4}(\mathrm{M}, \mathrm{f}) \mathrm{S}$ (4) and $\mathrm{C}_{2}(\mathrm{~A}, \mathrm{~F})$ phase enriched with $\mathrm{MgO}$ and $\mathrm{SiO}_{2}$ (2), filling the areas between $\mathrm{MgO}$ crystals (3) and spinel MA (1). 


\subsubsection{Magnesia-Zirconia-Calcia Product (MCZ)}

The microstructure of MCZ product was characterized by the presence of coarse grains of magnesia clinker, visible in Figure 3 as dark grey areas, and the finer ones of calcium zirconate (exhibited in the SEM image as the light grey areas). The black areas stand for pores.

The deposition of Portland clinker formed on the MCZ product (Figure 4) was mainly composed of the hexagonal crystals of tri-calcium silicate $\mathrm{C}_{3} \mathrm{~S}$ [1] with the admixtures of $\mathrm{MgO}$ and $\mathrm{Al}_{2} \mathrm{O}_{3}$ oxides that both stabilize the alpha and beta belite phase. The amount of admixtures was detected as being at the maximum level, compared to occurring in the industrial clinkers [17]. Additionally, the inclusions of $\mathrm{C}_{2} \mathrm{~S}$ phase in $\mathrm{C}_{3} \mathrm{~S}$ were found in the formed coating.

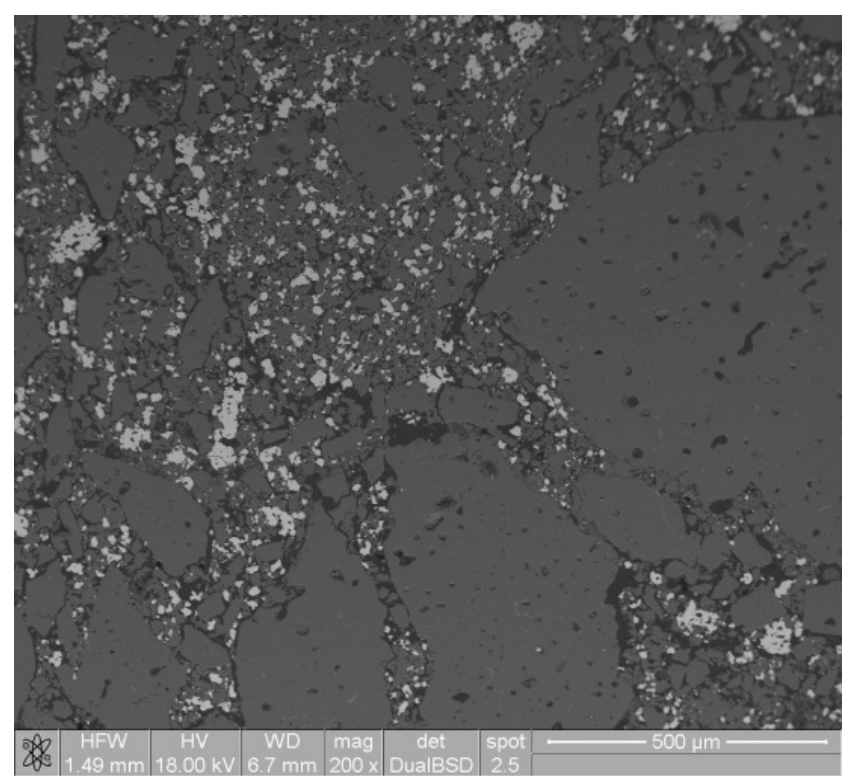

Figure 3. SEM image of the MCZ product, where light grains- $-\mathrm{CZ}$, dark grey areas $-\mathrm{MgO}$, light grey areas $-\mathrm{C}_{2} \mathrm{~S}$, black areas are pores.

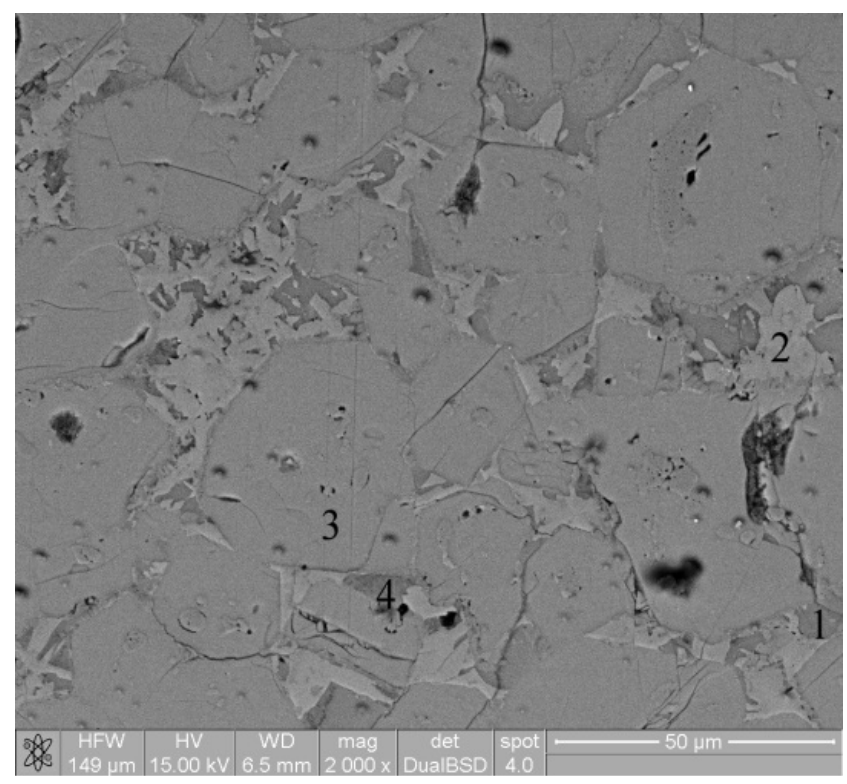

Figure 4. SEM image of deposition composed of mainly of clinker formed on the MCZ product. The areas between $\mathrm{C}_{3} \mathrm{~S}$ (3), with inclusions of $\mathrm{C}_{2} \mathrm{~S}$, are filled up by $\mathrm{C}_{3} \mathrm{~A}(1,4)$ and ss. $\mathrm{C}_{2}(\mathrm{~A}, \mathrm{~F})(2)$. 
The areas between alite crystals in the contact zone were filled up by the solid solution of aluminate ferrite phase $C_{2}(A, F)$ (Figure 5, point 3) with the observed inclusions of $C_{3} A$ (Figure 5, points 1 and 2). The admixtures of other oxides, typical for the industrial clinkers, were also detected in the above mentioned solid solutions. These were $\mathrm{MgO}$ in $\mathrm{C}_{3} \mathrm{~A}$, in higher amount when compared to the industrial clinker, as well as oxides $\mathrm{SiO}_{2}$ and $\mathrm{Fe}_{2} \mathrm{O}_{3}$, which reach the maximum level of their amount, present in the regular industrial clinker [17] [18]. Additionally, $\mathrm{MgO}, \mathrm{SiO}_{2}$ and $\mathrm{TiO}_{2}$ present in $\mathrm{C}_{2}(\mathrm{~A}, \mathrm{~F})$ phase occurred in the high amount in comparison to industrial clinker.

It was examined that the MCZ product was saturated in the area between $\mathrm{MgO}$ and $\mathrm{CZ}$ crystals by $\mathrm{C}_{3} \mathrm{~A}$ (Figure 6, point 3) and solid solution $C_{2}(A, F)$ (Figure 6, point 4) with rarely occurring $C_{2} S$ inclusions (Figure 6, point 5). The phases $\mathrm{C}_{3} \mathrm{~A}$ and $\mathrm{C}_{2}(\mathrm{~A}, \mathrm{~F})$ contained in their chemical composition the same admixtures as were

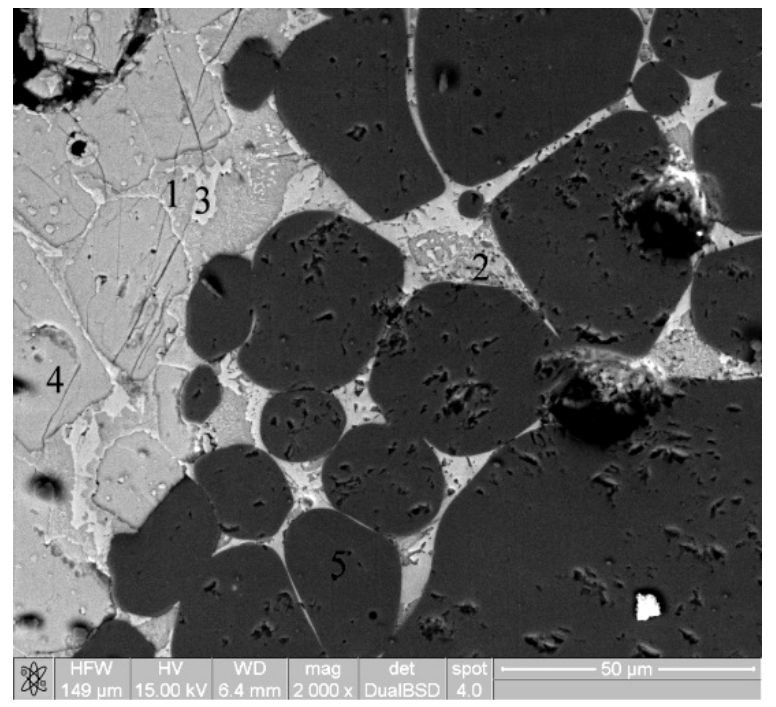

Figure 5. SEM image of the after-corrosion contact zone of the formed deposition composed of clinker on the MCZ product. Between $\mathrm{C}_{3} \mathrm{~S}$ crystals (4) in the deposition and MgO crystals (5) in the product, the ss. $\mathrm{C}_{3} \mathrm{~A}(1,2)$ as well as $C_{2}(A, F)(3)$ occur. The holes corresponds to pores.

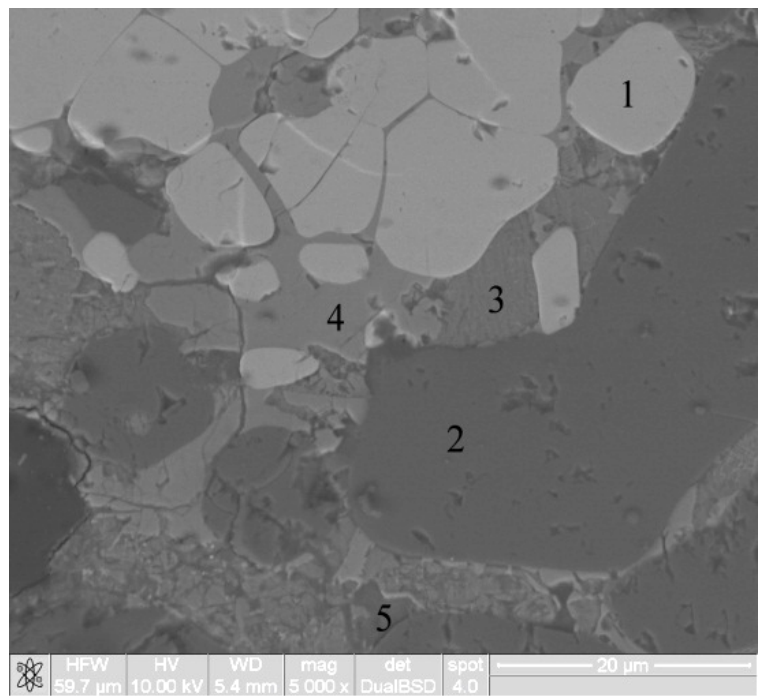

Figure 6. SEM image of the MCZ product after corrosion test with cement clinker. $\mathrm{MgO}(2)$ and $\mathrm{CaZrO}_{3}$ crystals (1) surrounded by the ss. of $\mathrm{C}_{3} \mathrm{~A}$ (3) and ss. of $\mathrm{C}_{2}(\mathrm{~A}, \mathrm{~F})(4)$ enriched with magnesium, silicon and zirconium with the inclusions of belite $\beta-\mathrm{Ca}_{2} \mathrm{SiO}_{4}(5)$. 
present in the area of the deposition, but with double amount of $\mathrm{Fe}_{2} \mathrm{O}_{3}$ and low amount of $\mathrm{Na}_{2} \mathrm{O}$. On the other hand, $\mathrm{C}_{2}(\mathrm{~A}, \mathrm{~F})$ phase, besides the dissolved $\mathrm{MgO}$ and $\mathrm{SiO}_{2}$ oxides, possessed also $\mathrm{ZrO}_{2}$. The chemical composition measured by EDS spectroscopy in point 4, indicated in Figure 6, was as follows: $\mathrm{MgO}-3.44 \%, \mathrm{Al}_{2} \mathrm{O}_{3}-$ $22.53 \%, \mathrm{SiO}_{2}-3.48 \%, \mathrm{CaO}-44.26 \%, \mathrm{Fe}_{2} \mathrm{O}_{3}-20.52 \%, \mathrm{ZrO}_{2}-5.77 \%$. In the chemical composition of $\mathrm{C}_{2} \mathrm{~S}$ phase admixtures of oxides like $\mathrm{MgO}, \mathrm{Al}_{2} \mathrm{O}_{3}, \mathrm{Na}_{2} \mathrm{O}$ and $\mathrm{K}_{2} \mathrm{O}$ were stated. These oxides possess ability to stabilize $\alpha, \alpha$, and $\beta-\mathrm{Ca}_{2} \mathrm{SiO}_{4}$ [19] and protect the material against deteriorated phase transition to $\gamma$-belite. Moreover, in the belite phase $\mathrm{ZrO}_{2}$ oxide was found, which also enable the stabilization of the $\alpha, \alpha$, and $\beta$ variants of the alite phase [1] [4].

\subsubsection{Magnesia-Hercynite Product (MH)}

As it can be observed from the cross section of the MH product, depicted in Figure 7, it is mainly composed of the coarse grains of magnesia clinker enriched with ferric oxide. The second component are fused hercynite grains, with their average size in the range of $0.2 \mathrm{~mm}-1 \mathrm{~mm}$, which are surrounded by the magnesia matrix. The periclase crystals reach $60 \mu \mathrm{m}$ in their average size and possess magnesium ferrite inclusions which are visible in the SEM image as small light dots. In addition, the Mg-Fe spinel was found as the phase that surrounds the $\mathrm{MgO}$ crystals together with di-calcium silicate. The crystals of fused hercynite are also not totally pure in their chemical composition. Besides $\mathrm{FeAl}_{2} \mathrm{O}_{4}$ phase, also the solid solutions of (Mg,Fe)( $\left.\mathrm{Al}, \mathrm{Fe}\right)_{2} \mathrm{O}_{4}$ and $\mathrm{CA}_{2}$ were detected. Furthermore, solid solution of $(\mathrm{Mg}, \mathrm{Fe})(\mathrm{Al}, \mathrm{Fe})_{2} \mathrm{O}_{4}$ was found as the phase surrounding the magnesia and hercynite grains along with the silicates as $\mathrm{C}_{2} \mathrm{~S}$ and $\mathrm{C}_{3} \mathrm{MS}_{2}$. This $(\mathrm{Mg}, \mathrm{Fe})(\mathrm{Al}, \mathrm{Fe})_{2} \mathrm{O}_{4}$ solid solution arises from dissolution and mutual partial diffusion of $\mathrm{Fe}^{2+/ 3+}$ and $\mathrm{Mg}^{2+}$ ions [11].

Hercynite grains (Figure 7, point 1), in $\mathrm{MH}$ product, composed of the solid solutions of $\mathrm{FeAl}_{2} \mathrm{O}_{4}$ and $\mathrm{MAF}$ dispersed in the matrix, underwent dissolution by the cement clinker components. Similarly, magnesioferrite surrounding periclase crystals was also dissolved by clinker.

In the image of the after-corrosion MH product (Figure 8) the solid solution $\mathrm{C}_{2}(\mathrm{~A}, \mathrm{~F})$ can be observed as lightgrey areas between $\mathrm{MgO}$ crystals (dark grey areas). This intermediate phase is additionally enriched with magnesium and silica oxides. Moreover, crystals of alite $\mathrm{C}_{2} \mathrm{~S}$ can be found, which are enriched with the admixtures such as $\mathrm{MgO}$ and $\mathrm{Al}_{2} \mathrm{O}_{3}$, that constitute components able to stabilize $\beta$ - and $\alpha^{\prime}-\mathrm{C}_{2} \mathrm{~S}$ [17]. In the larger distance from the contact zone of the $\mathrm{MH}$ product the areas between the isometric crystals of $\mathrm{MgO}$ are filled up by aluminate-ferrite phase of $\mathrm{C}_{4} \mathrm{AF}$ type, that was enriched with $\mathrm{SiO}_{2}$. This phase contains admixtures of MAF solid solution with small amounts of $\mathrm{SiO}_{2}, \mathrm{CaO}$ as well as the crystals of belite $\mathrm{C}_{2} \mathrm{~S}$ stabilized by $\mathrm{Fe}_{2} \mathrm{O}_{3}, \mathrm{Al}_{2} \mathrm{O}_{3}$ and $\mathrm{Na}_{2} \mathrm{O}$.

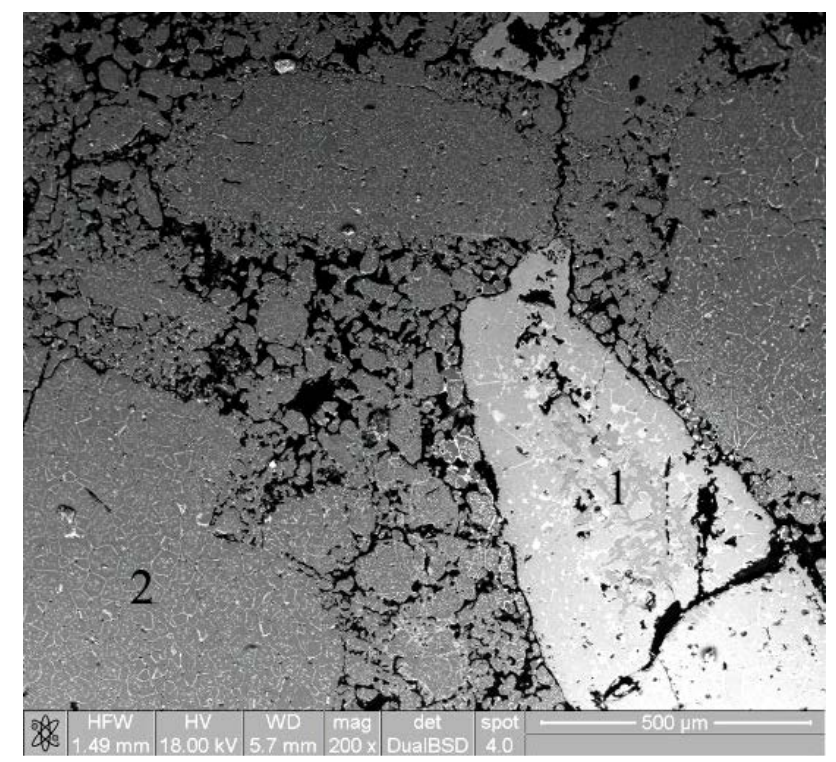

Figure 7. SEM image of the MH product, coarse grain of magnesia clinker (2) enriched with ferric oxide, grain of fused hercynite (1) located in the matrix of magnesia clinker. 


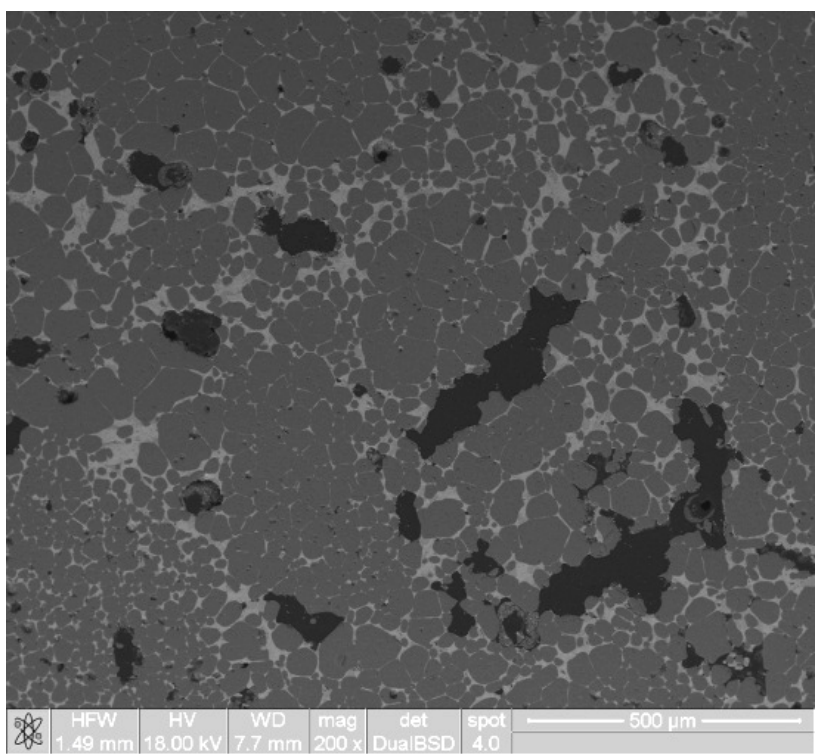

Figure 8. SEM image of the MH product after corrosion test with Portland clinker in the area close to the formed deposition.

\section{Summary and Conclusions}

Depending on the temperature, following the most important processes occur as a result of reaction between the components of the investigated products and the components of cement furnace charge:

-the amount of spinel MA decreases in the MSp product and calcium silicate of $\mathrm{C}_{3} \mathrm{~S}$ and calcium aluminate $\mathrm{C}_{3} \mathrm{~A}$ disappear in Portland clinker; after reaction at $1200^{\circ} \mathrm{C}$ calcium aluminate-mayenit $\mathrm{C}_{12} \mathrm{~A}_{7}$ (with melting point $1413^{\circ} \mathrm{C}$ ) is formed; after reaction at $1300^{\circ} \mathrm{C}$-the phase $\mathrm{C}_{6} \mathrm{~A}_{4}(\mathrm{M}, \mathrm{f}) \mathrm{S}$ (incongruently melting at $1380^{\circ} \mathrm{C}$ ) is formed (identified by X-ray analysis as so-called Q phase, expressed by the formula $\mathrm{C}_{20} \mathrm{~A}_{13} \mathrm{M}_{3} \mathrm{~S}_{3}$ ), and still exists at $1400^{\circ} \mathrm{C}$,

-the magnesia-zirconia-calcia product (MCZ) exhibits the excellent resistance to corrosion by both kiln hot meal and Portland clinker, in the range of temperature from $1200^{\circ} \mathrm{C}$ to $1400^{\circ} \mathrm{C}$, what is evidenced by the practically unchanged phase composition after the corrosion test under the above mentioned conditions. The conducted investigation showed that alternative materials for magnesia-spinel refractory are magnesia-zirconiacalcia materials,

-after coating corrosion test of the magnesia-hercynite product $(\mathrm{MH})$ dissolution of hercynite grains in the magnesia matrix was observed. Hercynite decomposed and products of its decomposition subsequently reacted with calcia, leading to formation of $\mathrm{C}_{2}(\mathrm{~A}, \mathrm{~F})$ or $\mathrm{C}_{4} \mathrm{AF}$ solid solutions, locating in the areas between magnesia grains and filling them very tightly. Taking into consideration kind of the reaction products, the magnesia-hercynite product will demonstrate an excellent ability to formation of the dense and stable protective coating.

\section{Acknowledgements}

The work was financially supported by the Polish State National Centre for Research and Development under Programme INNOTECH-K2/IN2/16/181920/NCBR/13.

\section{References}

[1] Kurdowski, W. (1991) “Chemia cementu”-“Chemistry of Cement” (in Polish), Scientific Publishing PWN, Warszawa, p. 27.

[2] Szczerba, J. (2005) “Ceramika”-Ceramics” (in Polish), 88, p. 110.

[3] Kühl, H. (1951) “Zement Chemie”-“Chemistry of Cement”. Verlag Technik Gmbh Berlin.

[4] Lea, F.M. (1972) The Chemistry of Cement and Concrete. Chemical Publ. Comp. Inc., New York.

[5] Bartha, P. (2004) Refractories Manual—Special Edition. InterCeram, 53, 14. 
[6] Szczerba, J. (1997) "Materiały Ogniotrwałe”-_Refractory Materials” (in Polish). 49 [2], p. 59.

[7] Ohno, M., Tokunaga, K., Tsuchiya, Y., Mizuno, Y. and Kozuka, H. (2003) Proceedings UNITECR’03, p. 27.

[8] Bogue, R.H. (1955) The Chemistry of Portland Cement. Rinhold Publ. Corp., New York.

[9] Szczerba, J. (2006) “Materiały Ceramiczne”_“Ceramic Materials” (in Polish), 58 [1], p. 6.

[10] Szczerba, J. (2010) Chemical Corrosion of Basic Refractories by Cement Kiln Materials. Ceramics International, 36, 1877-1885. http://dx.doi.org/10.1016/j.ceramint.2010.03.019

[11] Liu, G., Li, N., Yan, W., Tao, G. and Li, Y. (2012) Composition and Structure of a Composite Spinel Made from Magnesia and Hercynite. Journal of Ceramic Processing Research, 13, 480-485.

[12] Kapralik, I. and Hanic, F. (1964) Transaction of British Ceramic Society, 79, 128.

[13] Turriziani, R. and Massazza, F. (1966) Annali di Chimica, 56, 1180.

[14] Polesnig, W. and Zednicek, W. (1984) InterCeram, 33, 49.

[15] Woerman, E., Hahn, T. and Eysel, W. (1965) American Ceramic Society Bulletin, 44, 299.

[16] Guinier, A. and Regourd, M. (1968) Proceedings of the 5th ICCC, Tokyo, I, p. 1.

[17] Regourd, M. and Guinier, A. (1974) Proceedings of the 6th ICCC, Moscow, I, p. 25.

[18] Ghosh, S.N. (1980) Proceedings of the 7th ICCP, Paris, II, II-18.

[19] Woerman, E., Hahn, T. and Eysel, W. (1965) American Ceramic Society Bulletin, 44, p. 299. 